\title{
Botanical research of the medicinal plant Polygonum amphibium L. in the vicinity of Almaty City
}

\section{Natalia V. Kurbatova,}

\author{
Abibulla A. Ametov, \\ Nashtay M. Mukhitdinov, \\ Karime T. Abidkulova \\ Scientific Research Institute of \\ Biology and Biotechnology Problems, \\ Al-Farabi Kazakh \\ National University, \\ Almaty City, Kazakhstan
}

The purpose of the research conducted was the study of three populations of Polygonum amphibium L. The populations were discovered on the territory of Almaty Region: Frunzenskiy Pond (Ostemir, Talgar District), Lake Kishi Charyn (Amangeldy, Talgar District), Pervomayskiye Ponds (Tuimebayev, Ile District). The study included the estimation of raw medicinal plant stocks of the species indicated. The vegetation study was performed in compliance with the standard methods of field geobotany, and the estimation of medicinal plants stocks (the thicket area, yield, and potential annual procurement) was conducted according to the methods of A. I. Shreter, A. I. Polozhiy, and L. P. Ashmarin. As a result of work performed, the locations of three populations of Polygonum amphibium were established, geobotanical and floristic descriptions of associations were made, and herbarium specimens of species as well as seed material were collected. During the route reconnaissance investigation via GPS navigation, the following coordinates of the found populations of $P$. amphibium were fixed: population $1-\mathrm{N}^{\circ} 33^{\circ} 3.153^{\prime}$ and E $077^{\circ} 15.985^{\prime}$; population $2-\mathrm{N} 43^{\circ} 29.991^{\prime}$ and E $077^{\circ} 21.165^{\prime}$; population $3-\mathrm{N} 43^{\circ} 22.555^{\prime}$ and $\mathrm{E} 076^{\circ} 54.716^{\prime}$.

Key words: raw material stocks, medicinal plant, Polygonaceae Juss., plant association

\section{INTRODUCTION}

Nowadays, the issue of using natural resources rationally and preserving the biodiversity of essential plants is ever more relevant. One of the main sources of species diversity of medicinal

\footnotetext{
*Corresponding author. E-mail: karime_58@mail.ru
}

plants is wild-growing flora, so the task of its complex inventory and study of the peculiarities of its origin gains particular importance. At the same time, the necessity for careful and rational use of available resources of wild-growing medicinal plants in the Republic of Kazakhstan should be borne in mind. 
Since Kazakhstan gained independence, the production of medicines from medicinal plants in the country has been directly connected with the problem of providing the domestic pharmaceutical industry with sufficient plant raw materials. This is why, for its development, the pharmaceutical industry needs a stable supply of raw materials, either from an increased harvest of wild medicinal plants or from their cultivation.

To increase the range of listed species, a comprehensive study of the biological properties and chemical composition of potential medicinal plants is required. In this respect, the study of the botanically underexplored species, water knotweed (Polygonum amphibium L.) of the buckwheat family, Polygonaceae Juss., is both of theoretical and practical interest.

The following data is available on the use of $P$. amphibium in conventional and traditional medicine, as well as on the content of biologically active substances present: as a medicinal raw material, $P$. amphibium is widely used in medicine; in the Trans-Baikal Region the species is used to treat gout and diabetes; in Austrian folk medicine it is used in the treatment of nasal polyps and carcinomas; in Armenia it is used against haemorrhoids and as a diuretic; the decoction and infusion from the roots of this species are used as anti-neuralgic agents in cases of rheumatism, syphilis, oedema, breakdowns of the nervous and endocrine system, and for bone fractures in Tajikistan; the infusion from its leaves is a diuretic used to treat gall stones. This plant is resiniferous (Plant Resources, 1991).

Chemical and pharmaceutical studies of some species of the genus Polygonum L. have been conducted showing that the biological activity of the considered extracts and ingredients is high. Thus, the active ingredients of Polygonum amphibium isolated from methanol extract have a cytotoxic effect on people with leukemic cell lines. The isolated compounds 1 and 2 are considered to be good candidates for use as chemotherapeutic agents in the treatment of leukaemia (Smolarz, Budzianowski et al., 2008).
When studying the phytochemistry of some species of the genus Polygonum, a number of scientists have determined the chemical composition and antioxidant activity of the P. amphibium collected on Lake Vlasina in Serbia. According to their data, a polyphenol profile of $80 \%$ alcohol extract from the stems, leaves, and flowers has been determined, and the whole plant of this species contains 45 phenolic compounds. In all studied extracts, quercetin and its glycosides, hyperoside and isoquercetin, which account for up to $4 \%$ of dry extract from the leaves of $P$. amphibium, are acknowledged to be the dominant phenols. The antioxidant activity of extracts after their purification has also been determined (Svirčev, Balog et al., 2010).

As this species is of great interest as a potential medicinal plant, and insufficient botanical information is available, we present here the research results of the composition of three populations of $P$. amphibium vegetation and the estimation results of raw material stocks of this medicinal plant.

\section{MATERIALS AND METHODS}

In the process of the work, studies of plant associations were conducted in accordance with standard methods (Field Geobotany, 1976). The nomenclature was provided according to the summaries of S. A. Abdulina (1999) and S. K. Cherepanov (1995). The estimation of yield was carried out according to the typical quadrat procedure during the route reconnaissance investigation. We arranged the $1 \mathrm{~m}^{2}$ quadrats evenly, from space to space. To estimate the medicinal raw material stocks we considered two indicators: the thicket area and productivity. The thicket area was determined by equating the outlines of the thicket with a geometric figure (a square) and then measuring parameters (length, width) necessary for the calculation of the area of this figure. In cases where the areas of the studied species were situated unevenly in separate spots within the plant association, we at first determined the area of 
the whole spot where the studied species was found and then determined the percentage of the area occupied by the studied species. To estimate the yield we laid the $1 \mathrm{~m}^{2}$ quadrats in such a way that it could be possible to embrace the whole field area (thicket). The quadrats were arranged in parallel lines, diagonally, or in an envelope-like form. The square quadrats were laid at intervals of several meters $(3-5 \mathrm{~m})$ regardless of presence or absence of the studied species in the given place. Then all the epigeal raw material phytomass was collected on each quadrat. Shoots, juvenile and damaged samples were not subject to collection. The raw material collected from a quadrat was weighed to $\pm 5 \%$ accuracy. The estimation of raw material stocks and the determination of yield were carried out using standard methods (Shreter, 1986; Polozhiy, 1988; Ashmarin, 1975).

\section{RESULTS AND DISCUSSION}

In Kazakhstan the genus Polygonum L. is represented by 48 species along with one endemic, Polygonum betpakdalense Bait. (The Flora of Kazakhstan, 1960; Baytenov, 2001).

Polygonum amphibium L. ("tamyrdary" in the Kazakh pronunciation) is a perennial plant. The rhizome is creeping, ramified, rooting at the nodes. The stem is up to $1 \mathrm{~m}$ in height, erect, simple, with accumbent or bristly hairs or immersed in water, bare, strongly elongated, ramified, flexible. The ochreas firmly investing the stem are up to $15 \mathrm{~mm}$ long, brownish, smooth, obtuse. The leaves are $5-12 \mathrm{~cm}$ in length and $1.5-4 \mathrm{~cm}$ in width, oblong and lanceolate, almost sessile, with accumbent hairs in the land form, and floating on water, oblong, shortly acuminate, with base rounded, long-petiolate, smooth, sleek in the aquatic form. The inflorescence is $3-5 \mathrm{~cm}$ in length, apical, spicate, thick, on a strong peduncle; the perianth is about $3-5 \mathrm{~cm}$ in length, hot-pink or white, deeply divided into bluntish laciniae; the number of stamens is (4)5-(8). The nutlets are $2.5-3 \mathrm{~mm}$ in length, rounded, convex on both sides, black, shiny, with a vaguely wrinkled surface. Flowers appear from June to September.

The aquatic form grows in slow-flowing or still water: in oxbow lakes, ordinary lakes, backwaters, small rivers. The land form grows along sandy and clayey banks, on riverside meadows, and on roadsides.

The plant is found in all regions of $\mathrm{Ka}$ zakhstan.

General area of distribution: the European part of the former USSR, the Caucasus, Central Asia, Western and Eastern Siberia, the Far East, Western Europe, Asia Minor, Iran, India, China, Japan, North America (The Flora of Kazakhstan, 1960; Baytenov, 2001).

In 2012, during the exploration of the Talgar, Ile and Yenbekshikazakh districts of Almaty Region and after performing the corresponding search, the locations of three populations of $P$. amphibium were established. Based on the data obtained, the locations of the knotweed populations were plotted on a map (Fig. 1).

The first studied population of P. amphibium was found on Frunzenskiy Pond, on the River Saztalgar near Ostemir in Talgar District of Almaty Region (Fig. 2).

The explored pond is $1.039 \mathrm{~m}$ in length and $121 \mathrm{~m}$ in width. The natural thickets of water knotweed here occupy an area of about 237.2 ha.

The vegetation in the water was present as the pondweed and knotweed association (Potamogeton lucens L., P. natans L., P. pamiricus Baagoe - Polygonum amphibium). The projective cover on the water surface in the densest thickets amounted to $60-65 \%$. At the spots where Polygonum amphibium grew evenly, the projective cover was $34-40 \%$. In the remaining parts of the water body the projective cover did not exceed 15-20\%.

Below the water surface, the herb thickets were very dense, especially in the shallow spots near the banks. It was observed that the algae were present as the genus Chara of the Charophyta division.

Higher, at the watersheds, xerophytes such as Achnatherum splendens (Trin.) Nevski, 


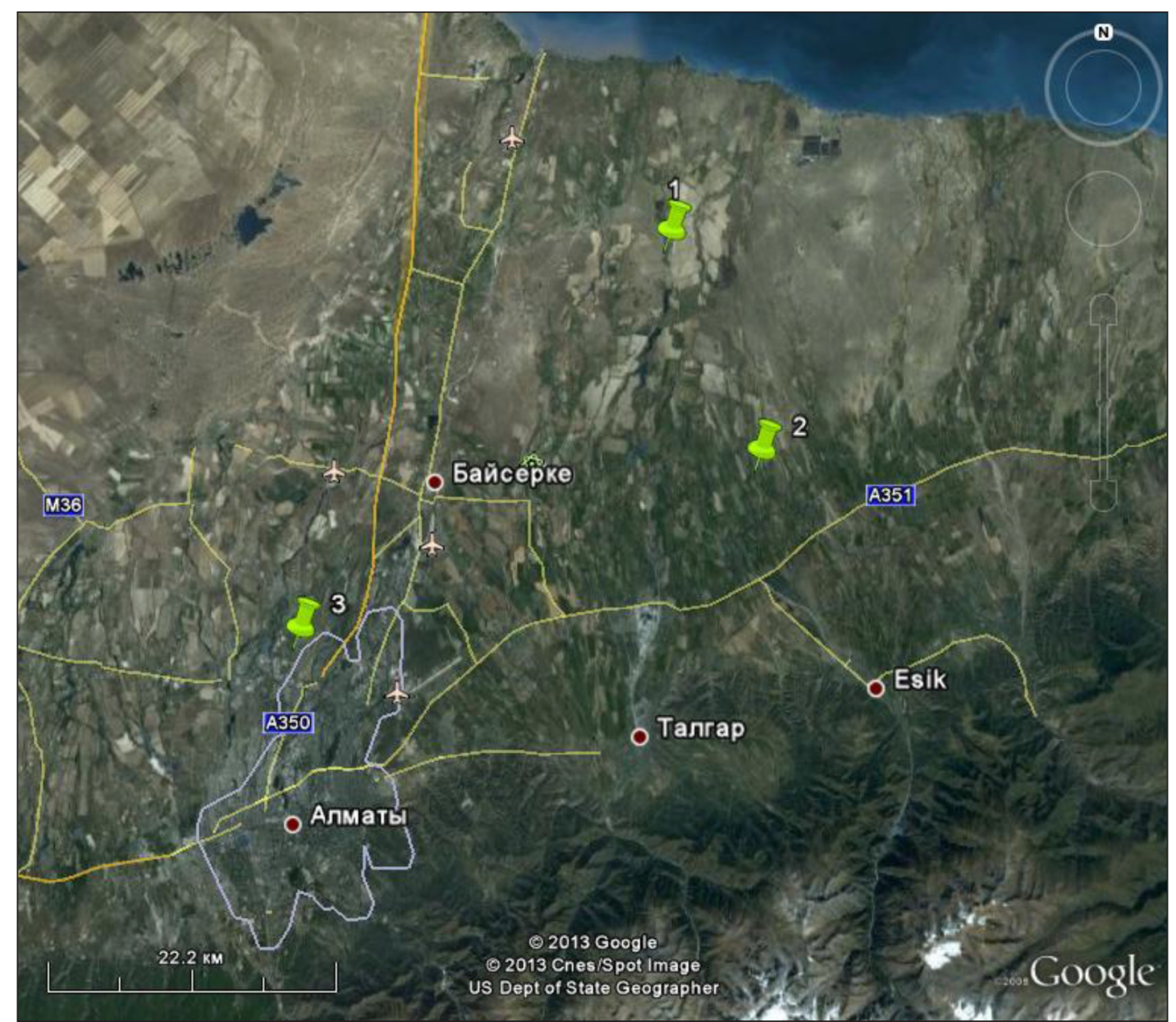

Fig. 1. Map showing the location of three populations of Polygonum amphibium (1 - population 1,2-population 2, 3 - population 3 )

Calamagrostis dubia Bunge, Artemisia terraealbae Krasch., Artemisia vulgaris L., and Marrubium vulgare L. primarily grew; weeds such as Cannabis ruderalis Janisch., Urtica cannabina L., Peganum harmala L., and others were present.

The floristic composition of the pond's embryophytes was not rich except for the coastal marsh plants. We have detected and defined four species of pondweeds directly in the water: Potamogeton natans, $P$. perfoliatus L., P. lucens L., P. pamiricus. Additionally, such species as Najas marina L. and Polygonum amphibium were found. The coastal marsh plants were represented by such species as Phragmites australis (Cav.) Trin. ex Steud., Bolboschoenus maritimus (L.) Palla, Typha angustifolia L., Juncus compressus Jacq., Butomus umbellatus L., Sparganium stoloni- ferum (Graebn.) Buch.-Ham. ex Juz., and Rorippa palustris (L.) Besser.

The second population of Polygonum amphibium was found on Lake Kishi Charyn in Talgar District of Almaty Region (Fig. 3).

The length of the explored lake was $232 \mathrm{~m}$, its width $-74 \mathrm{~m}$. The average depth was $2-3 \mathrm{~m}$. On the lower eastern bank of the lake, dense thickets of Phragmites australis were found. Along the northern bank of the lake, lesser amounts of Phragmites australis thickets were found. Phragmites australis was absent on the western and north-western banks of the lake. Here, near the water, thickets of sedge and reed mace were found. In addition, Rorippa palustris, Chloris virgata Sw. and Butomus umbellatus were found. Higher, at the watersheds, xerophytic and mesoxerophytic herbs including Pseudosophora alopecuroides (L.) Sweet, Artemisia terrae- 


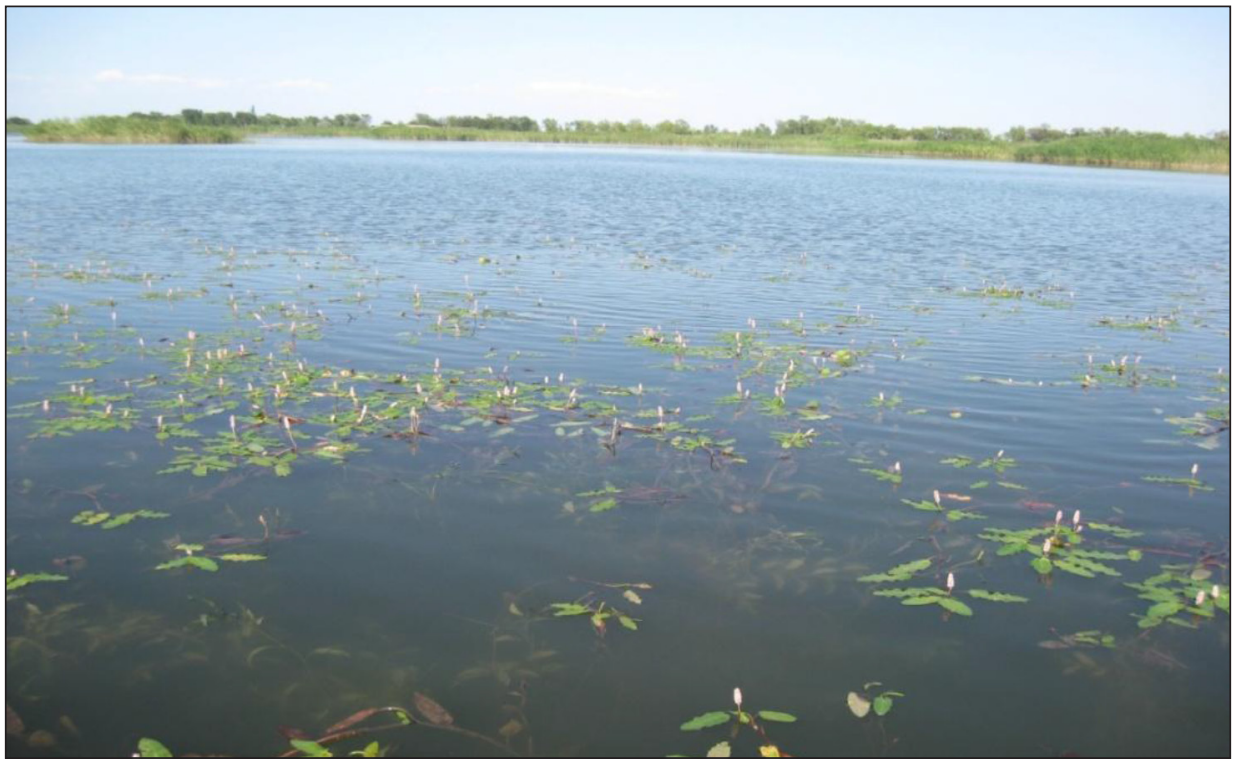

Fig. 2. Population 1 of Polygonum amphibium on Frunzenskiy pond

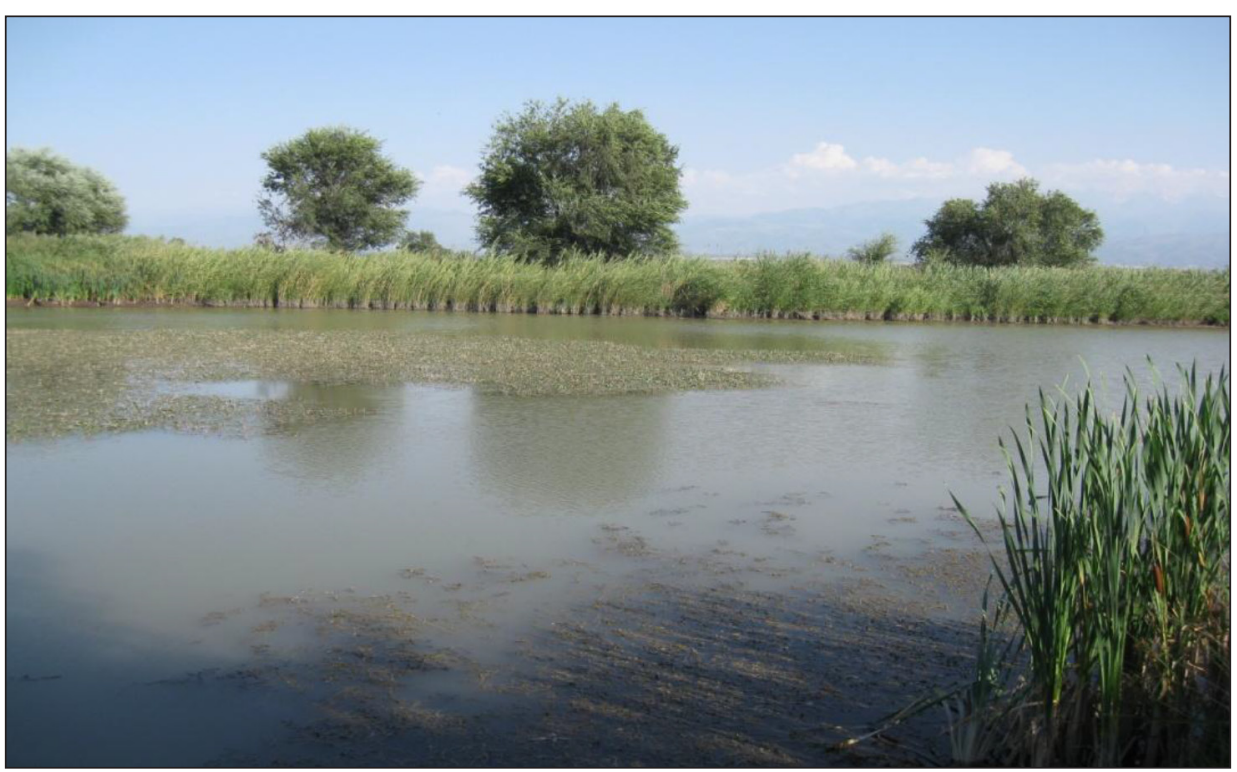

Fig. 3. Polygonum amphibium population on Lake Kishi Charyn

albae, Kochia prostrate (L.) Schrad., Alhagi kirghisorum Schrenk were found.

In the waters of this lake, two plant associations were found. The first one was purely a knotweed association (Polygonum amphibium). Polygonum amphibium grew here in large and small clusters. The projective cover amounted to $85-90 \%$. The second association was a knotweed and pondweed association (Polygonum amphibium - Potamogeton natans, P. perfoliatus, $P$. lucens, $P$. pamiricus). This association was located closer to the banks of the lake. About
$60 \%$ of the projective cover was occupied by the pondweed species, while Polygonum amphibium accounted for no more than $40 \%$. In general, the Polygonum amphibium thickets occupied no more than $35-45 \%$ of the lake's waters.

The floristic composition of these two associations was poor and included the same six species of embryophytes that were present in the first population (Frunzenskiy Pond). Among these were plants of the Potamogetonaceae Dumort. family: Potamogeton natans, P. perfoliatus, P. lucens, P. pamiricus. Apart from these 


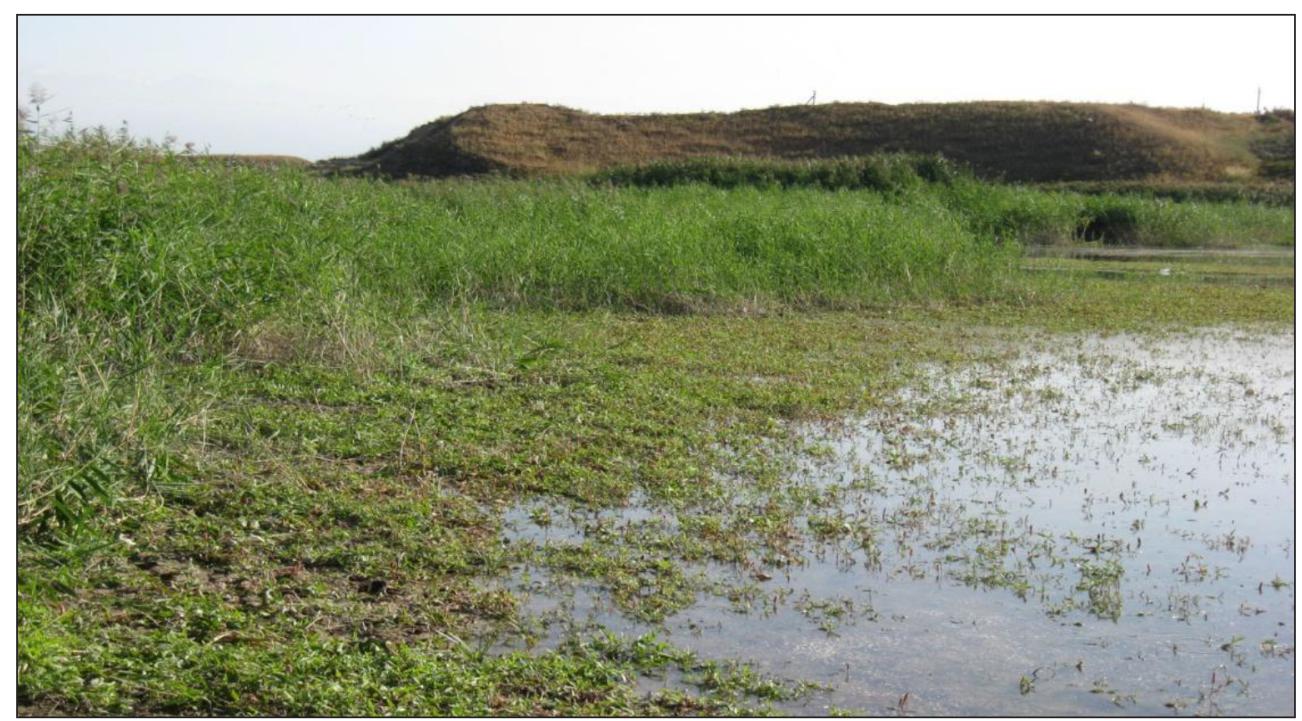

Fig. 4. Population 3 of Polygonum amphibium on the Pervomayskiy Pond near Tuimebayev

species, Najas marina of the Najadaceae Juss. family and Polygonum amphibium were found. Chara of the Charophyta division was part of the vegetation cover as a representative of macroalgae.

The third population of $P$. amphibium was found on the Pervomayskiy Pond near Tuimebayev in Ile District of Almaty Region (Fig. 4).

The banks of the pond where the research was conducted are high and steep. Along the banks dense thickets of Phragmites australis were found. In places Typha angustifolia grew in clusters along with Bolboschoenus maritimus. Along the banks of the pond Butomus umbellatus was also found, and along the waterline there grew sedge, Cyperus fuscus L., Pycreus sanguinolentus (Vahl) Nees., Mentha arvensis L., Echinochloa crusgalli (L.) Beauv., etc. The water level in the pond changes depending on the season: it falls notably by autumn and rises in the period of spring thaw and abundant rain. As a result, favourable conditions for the growth of aquatic plant species, especially $P$. amphibium, are created. When the water level of the pond dropped notably by the end of summer, the aquatic species of the embryophytes found themselves within the beach line of the pond. Moreover, many of them, especially species of the genus Potamogeton,

Table. Stocks of the medicinal plant Polygonum amphibium

\begin{tabular}{c|c|c|c|c|c}
\hline $\begin{array}{c}\text { Name of the raw } \\
\text { material and the } \\
\text { part used / No. of the } \\
\text { population }\end{array}$ & $\begin{array}{c}\text { Place of } \\
\text { research }\end{array}$ & $\begin{array}{c}\text { Number of } \\
\text { quadrats, } \\
\text { pieces }\end{array}$ & $\begin{array}{c}\text { Thicket } \\
\text { area, ha }\end{array}$ & $\begin{array}{c}\text { Wet weight } \\
\mathbf{M} \pm \mathbf{m}, \mathbf{g} / \mathbf{m}^{2}\end{array}$ & $\begin{array}{c}\text { Air-dry weight } \\
\mathbf{M} \pm \mathbf{m}, \mathbf{g} / \mathbf{m}^{2}\end{array}$ \\
\hline $\begin{array}{c}\text { Polygonum amphibium } \\
\text { (epigeal portion) } \\
\text { (population 1) }\end{array}$ & $\begin{array}{c}\text { Frunzenskiy } \\
\text { Pond }\end{array}$ & 15 & 237.2 & $568.0 \pm 60.0$ & $82.8 \pm 8.7$ \\
\hline $\begin{array}{c}\text { Polygonum amphibium } \\
\text { (epigeal portion) } \\
\text { (population 2) }\end{array}$ & $\begin{array}{c}\text { Lake Kishi } \\
\text { Charyn }\end{array}$ & 15 & 172.0 & $3.694 \pm 185.0$ & $440.0 \pm 34.6$ \\
\hline $\begin{array}{c}\text { Polygonum amphibium } \\
\text { (epigeal portion) } \\
\text { (population 3) }\end{array}$ & $\begin{array}{c}\text { The } \\
\text { Pervomayskiy } \\
\text { Pond }\end{array}$ & 15 & 233.0 & $1.278 \pm 106.0$ & $385.0 \pm 49.0$ \\
\hline
\end{tabular}


started withering. However, P. amphibium adapted to these conditions and took on an epigeal form. Particularly, the number of internodes decreased significantly, the lamina gained a lanceolate form and became thicker and glossier. On the Pervomayskiy Pond a purely knotweed association (Polygonum amphibium) was described. The projective cover amounted to $90-95 \%$ in the water and $100 \%$ in the coastal strip. All the above-mentioned species of aquatic and coastal aquatic plants did not take part in forming plant associations of pond and coastal strip. They formed a coastal wetland.

The floristic composition of this association was not rich and included only six species. Four of them were pondweed species: Potamogeton natans, $P$. perfoliatus, $P$. lucens, $P$. pamiricus. Apart from these, Najas marina and Polygonum amphibium were found (as in the previous population). However, it should be noted that Bolboschoenus maritimus and Phragmites australis alternated along with these aquatic plants on the skirts of the association, but these species had almost no part in forming the association. Algae were present as separate bushes of species of the genus Chara.

The next stage in the work was to determine the thicket area, yield, and potential commercial stocks of plant raw material. Based on the data obtained, the summarizing table was compiled.

The results in the table show that the highest yield (air-dry weight) of $440.0 \pm 34.6 \mathrm{~g} / \mathrm{m}^{2}$ is characteristic of the Polygonum amphibium growing on Lake Kishi Charyn, followed by the area of the Pervomayskiy Pond, with a yield of $385.0 \pm 49.0 \mathrm{~g} / \mathrm{m}^{2}$ (according to the data obtained), with the lowest values of $82.8 \pm 8.7 \mathrm{~g} / \mathrm{m}^{2}$ recorded for the first population on Frunzenskiy Pond.

\section{CONCLUSIONS}

Thus, in three studied populations of P. amphibium directly in the water, we registered six species of the aquatic embryophytes related to three families and three genera. Five species of the above-mentioned six aquatic embryophytes are hemicryptophytes, i. e. perennial plants. One species, Najas marina, relates to the therophytes, i.e. annual plants. The thallophytes are presented by the macroalgae Chara which was the constant component of the associations wherein P. amphibium was found. All the species mentioned above relate to hydrophytes and are benthic plants.

Regarding raw material stocks, the obtained data indicate the availability of fairly large thicket areas of $P$. amphibium. However, because this species is characterised by the presence of a significant amount of aquiferous parenchyma, its air mass decreases practically 8-10 times after its desiccation. This significantly reduces the yield of the species and should be taken into consideration in the procurement of raw material.

It should also be noted that the studied species is very fastidious about water environment conditions, and was not found in all water bodies explored by us. The probable reason may lie, firstly, in the fact that $P$. amphibium cannot withstand pollution of water bodies, or, secondly, in the fact that $P$. amphibium is selective to the gas and salt composition of the water body, or, thirdly, in the fact that it is sensitive to the temperature regime of the water body. This is why the natural raw material stocks of this species in the water bodies of Almaty Region are low and insufficient for the unlimited procurement of raw material, and the creation of artificial plantations would entail serious difficulties of a technical, as well as a practical, nature and demand huge investments.

\section{ACKNOWLEDGEMENTS}

This research was carried out as a part of the grant project "Botanical Research of Some Potential Species of the Polygonaceae Juss. (Genus Polygonum L.) Family of the Local Flora" sponsored by the Ministry of Education and Science of the Republic of Kazakhstan.

Received 5 March 2013 Accepted 3 September 2013 


\section{References}

1. Abdulina SA. Checklist of Vascular Plants of Kazakhstan. Under the editorship of RV. Kamelin. Almaty, 1998, 187 p.

2. Ashmarin LP. Quick Methods of Statistical Processing and Planning of Experiments. Ashmarin LP, Vasilyev NN, Ambrosov VA. L.: Leningrad University Publishers, 1975, 78 p.

3. Baitenov MS. The Flora of Kazakhstan. Almaty, "Nauka", 2001; 2: 280 p.

4. Czerepanov SK. Vascular Plants of Russia and Adjacent States (the former USSR). Cambridge University Press, 1995, 516 p.

5. Field Geobotany. Under the editorship of Lavrenko YeM, Korchagin A A. Publishing house of the Academy of Sciences of the USSR, 1976, $320 \mathrm{p}$.

6. Polozhiy AI. Methodical Guidelines to the Study of Siberian Medicinal Plant Resources. Polozhiy AI, Nekratova NA, Timoshok YeYe. Abakan, 1988, 2-91.

7. Plant Resources of the USSR. Flowering plants, their chemical composition and use. Under the editorship of Sokolov PD. M., 1991, 245-92.

8. Smolarz HD, Budzianowski J, BoguckaKocka A, Kocki J, Men E. Flavonoid glucuronides with anti-leukaemic activity from Polygonum amphibium L. Phytochem Analys 2008; 19(6): 506-13.

9. Svirčev E, Balog K, Lesjak M, MimicaDukic N, Orcic D, Franciškovic M, Simin N. Antioxidant activity and polyphenolic composition of water knotweed (Polygonum amphibium L.) ethanolic extracts. Grasas y aceites (Sevilla) 2010; 61(1): 86-94.

10. Shreter AI. Procedure for Estimation of Medicinal Plant Stocks. Shreter AI, Krylova IL. M., 1986, 2-33.

11. Flora of Kazakhstan. Under the editorship of Pavlov NV. Alma-Ata, the Academy of Sciences of the KazSSR, 1960; Vol. 3: 90-105.

\section{N. V. Kurbatova, A. A. Ametov, \\ N. M. Mukhitdinov, K. T. Abidkulova \\ MEDICININIO AUGALO POLYGONUM AMPHIBIUM L. NETOLI ALMATOS MIESTO BOTANINIS TYRIMAS}

\section{Santrauka}

Tyrimo tikslas buvo ištirti tris Polygonum amphibium L. populiacijas, rastas Almatos regione: Frunzenskiy tvenkinyje (Ostemir, Talgar rajone), Kishi Charyn ežere (Amangeldy, Talgar rajone), Pervomayskiye tvenkiniuose (Tuimebayev, Ile rajone). Tyrimas apèmé nurodyto medicininio augalo žaliụjų rūšies išteklių nustatymą. Remiantis standartiniais geobotaniniais metodais buvo atliktas vegetacijos tyrimas ir nustatyti medicininių augalų ištekliai (tankumas, kiekis ir potencialus metinis supirkimas) pagal I. Shreter, A. I. Polozhiy, ir L. P. Ashmarin metodiką. Tyrimu nustatytos trijų populiacijų Polygonum amphibium augavietès, atliktas geobotaninių ir floristinių ryšių apibūdinimas, surinkti rūšių herbarų pavyzdžiai, sèklų medžiaga. Atliekant kelio žvalgymą GPS navigacija, nustatytos šios $P$. Amphibium po-

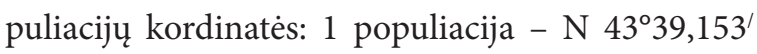
ir E $077^{\circ} 15,985^{\prime}$; 2 populiacija $-\mathrm{N} 43^{\circ} 29,991^{\prime}$ ir E $077^{\circ} 21,165^{\prime} ; 3$ populiacija $-\mathrm{N} 43^{\circ} 22,555^{\prime}$ ir E $076^{\circ} 54,716^{\prime}$.

Raktažodžiai: žaliosios medžiagos ištekliai, medicininis augalas, Polygonaceae Juss., augalų bendrija 